\title{
Establecimiento de bacterias benéficas en el tracto digestivo y gónada de adultos de Argopecten purpuratus (Lamarck 1819) en cultivo masivo
}

\author{
Establishment of beneficial bacteria in the digestive tract and gonads of adult \\ Argopecten purpuratus (Lamarck 1819) in mass culture \\ Ruben E. Avendaño-Herrera, Marcelo Dekovic y Carlos E. Riquelme. ${ }^{1}$ \\ ${ }^{1}$ Laboratorio de Microbiología Marina, Departamento de Acuicultura, Universidad de Antofagasta. Casilla 170, Antofagasta. \\ criquelme@uantof.cl
}

Resumen.- El objetivo del presente estudio es evaluar la factibilidad de establecer las bacterias benéficas 11, C33 y 77 en el tracto digestivo de reproductores de Argopecten purpuratus y determinar la infección gonadal de los organismos tratados, utilizando como vector de incorporación cultivos axénicos de Isochrysis galbana. El estudio se realizó en tres etapas experimentales: 1) "in vitro", correspondiente a experiencias de ingestión de bacterias benéficas, 2) ensayos pilotos, en estanques de $200 \mathrm{~L}$ y 3) ensayos masivos en estanques de $2000 \mathrm{~L}$ en un cultivo comercial. Los resultados de ingestión en adultos de $A$. purpuratus revelaron la ingestión de las cepas 11 y $\mathrm{C} 33$ en un $92 \%(\mathrm{P}<0,05)$. Al evaluar el establecimiento en el tracto digestivo de los ejemplares alimentados con la dieta I. galbana asociada a las cepas 11, C33 y 77 (Microalga y Bacterias Probióticas, MBP), sólo se detectó la presencia de la cepa $11(41,8 \%)$. El análisis de los cortes histológicos reveló en los organismos expuestos al tratamiento de dieta MBP un incremento de bacterias adheridas a las microvellosidades del tracto digestivo. Los resultados en los ensayos masivos mostraron el asentamiento de la cepa 11 en todos los ejemplares alimentados con la dieta MBP, fluctuando entre 34,12 a 75,64\% UFC x g-1 . De igual modo, se detectó la infección gonadal de los organismos examinados mediante cultivos tradicionales. Nuestros resultados permiten concluir que es factible utilizar el vector alimento para establecer la cepa 11 en el tracto digestivo y gónada de $A$. purpuratus. Además, la adición de estas bacterias no causa efectos negativos en la sobrevivencia de reproductores de estos organismos.

Palabras claves: Bacterias benéficas, Argopecten purpuratus, tracto digestivo, gónada

\begin{abstract}
The objective of the present study was to evaluate the feasibility of establishing beneficial (probiotic) bacterial strains 11, C33, and 77 in the digestive tracts of broodstock of the scallop Argopecten purpuratus. Colonization of digestive tract and gonad in the scallops was attempted by feeding them with mix culture of Isochrysis galbana and the benefical bacterial strains. The study was carried out in three experimental stages :1) "in vitro" testing evaluated ingestion of the beneficial bacteria by the scallops; 2) pilot assays in tanks of $200 \mathrm{~L}$ and 3) large (production) scale assays in $2000 \mathrm{~L}$ commercial culture tanks. Results of ingestion of bacteria by adult $A$. purpuratus showed $92 \%$ ingestion of strains 11 and $\mathrm{C} 33(\mathrm{P}<0.05)$. Evaluation of colonization of the digestive tract in specimens fed with a diet of I. galbana associated with strains 11, C33, and 77 (Bacterial Probiotic Mixture MBP) showed only the presence of strain $11(41.8 \%)$. Analysis of histological sections showed that scallops exposed to MBP treatment showed large numbers of bacteria adhered to microvilli in the digestive tract. The results of the large scale assays showed settlement of bacterial strain 11 in all specimens fed with the MBP diet, in numbers fluctuating between 34.12 and 75.64 UFC g $^{-1}$. Similarly, gonadal colonization was detected in scallops examined by means of traditional plate cultures. The results allow the conclusion that it is feasible to use the microalgae as a vector for the introduction of probiotic bacterial strain 11 into the digestive gland and gonad of A. purpuratus. Also, addition of these bacteria did not cause deleterious effects on survival of these broodstock.
\end{abstract}

Keywords: beneficial bacteria, Argopecten purpuratus, digestive tract, gonad.

\section{Introducción}

El cultivo artificial del "ostión del norte" Argopecten purpuratus (Lamarck 1819), ha tenido en los últimos años un fuerte desarrollo productivo, generando a Chile retornos cercanos a los US\$13 millones y más de 3600 empleos directos e indirectos (Lozano 2000). Sin embargo, la producción artificial de semillas se ha visto limitada (Navarro et al. 1991, Disalvo 1991, Fitt et al. 1992, Riquelme et al. 1995a) por la ocurrencia de mortalidades larvales masivas originadas, entre otros factores a infecciones causadas por bacterias del género Vibrio (Robert et al. 1996). 
Una de las medidas más recurrentes para contrarrestar la proliferación de estas cepas patógenas, es la utilización de antibióticos (Gibson et al. 1998). No obstante, el uso de estos quimioterapéuticos es cada día más limitado en el ámbito mundial, debido a la capacidad que poseen las bacterias de desarrollar una múltiple resistencia a estas substancias (Riquelme et al. 1994, Riquelme et al. 1996a, Skjermo \& Vadstein 1999) y a la lenta degradación de estos compuestos, los cuales causan graves perturbaciones medio ambientales en las aguas naturales que reciben este tipo efluentes (Boyd \& Massaut 1999). Una medida alternativa a estos compuestos antibacterianos es el control biológico, por medio de bacterias benéficas denominadas "probióticos", las cuales aplicados al hombre o animales, afectan benéficamente al hospedador mejorando el equilibrio en la microflora autóctona. (O’ Sullivan et al. 1992).

El interés de utilizar probióticos radica en que estos componentes biológicos mejoran el balance microbiano intestinal, la absorción de alimentos y reduce los problemas de patógenos en el tracto intestinal (Rengpipat et al. 1998). Además, las aplicación de estas bacterias en la acuicultura son diversas, siendo utilizadas frecuentemente como desinfectantes, osmorreguladores, algicidas, coagulantes, reductores de fósforo y nitrógeno, disociación de oxígeno, reductores de algas verdes azuladas y control de amonio-nitrito (Douillet \& Langdon 1993, Boyd \& Massaut 1999).

Durante los últimos años, han sido numerosos los trabajos realizados con bacterias benéficas en cultivos de organismos marinos de interés comercial (Westerdahl et al. 1991, Olsson et al. 1992, Nogami \& Maeda 1992, Bergh 1995, Ruiz et al. 1995, Riquelme et al. 1996a, Reid 1999, Harzevili et al. 1998, Gram et al. 1999, Gatesoupe 1999). En el caso particular de larvas de $A$. purpuratus ha sido demostrado el efecto protectivo de algunas bacterias benéficas en infecciones causadas por el patógeno Vibrio anguillarum (VAR), aumentando la sobrevivencia larval e inhibiendo el crecimiento del patógeno (Riquelme et al. 1997). De igual modo, diversos estudios han demostrado la incorporación, ingesta y colonización del tracto digestivo, por bacterias antagonistas en larvas del “ostión del norte" (Riquelme et al. 2000, Avendaño \& Riquelme 1999, Araya et al. 1999). La incorporación de los probióticos en los sistemas de cultivo, se realiza preferentemente tomando en cuenta las tres vías de ingreso descritas por Elston (1984): el flujo de agua, stock de reproductores y fuente de alimento. En el caso de organismos adultos, falta por determinar cual es la mejor vía de incorporación de las cepas benéficas a los sistemas de cultivo de $A$. purpuratus.
El objetivo del presente estudio es evaluar la factibilidad de establecer bacterias benéficas en el tracto digestivo de reproductores de $A$. purpuratus, utilizando como vector el alimento administrado regularmente en sistemas de cultivos y determinar infección de las gónadas en ejemplares de A. purpuratus tratados con bacterias benéficas.

\section{Materiales y Métodos}

El estudio se realizó en tres etapas experimentales. La primera etapa "in vitro", corresponde a experiencias efectuadas en el Laboratorio de Microbiología Marina de la Universidad de Antofagasta, la segunda etapa denominada "piloto", realizada en el "hatchery" de la Facultad de Recursos del Mar de la misma institución y la etapa masiva, realizada en el "hatchery" de la empresa Cultivos Marinos Internacionales S.A. (CMI, $27^{\circ} 03$ '02, 24'’S- 70³4'W).

\section{Obtención y análisis bacteriológico de especimenes:}

Se recolectaron 140 especímenes adultos de $A$. purpuratus desde un banco natural ubicado en la Bahía Mejillones, II Región de Chile (2303' S y $\left.70^{\circ} 33^{\prime} \mathrm{W}\right)$. Los ejemplares se obtuvieron mediante buceo autónomo a 20 metros de profundidad y fueron transportados en cajas de aislapol con esponjas de polietileno expandido y no naturales, húmedas hasta los estanques de acondicionamiento. Durante esta etapa los organismos fueron mantenidos durante 25 días en un estanque de concreto de $3000 \mathrm{~L}$, alimentándolos con aportes del plancton suministrado por la circulación de agua de mar filtrada a $50 \mu \mathrm{m}$.

Con el objeto de estimar la carga microbiana de $A$. purpuratus en su medio natural, se realizó un muestreo bacteriológico de 5 individuos antes de comenzar el período de acondicionamiento. Para ello, los organismos fueron lavados repetidas veces con solución salina estéril (SSM, Austin 1988) y disectados, separando el tracto digestivo y las gónadas de cada ejemplar. Las partes blandas fueron lavadas con SSM y concentradas en bolsas estériles con $9 \mathrm{ml}$ de $\mathrm{SSM}$ para homogeneizarlas en un Stomacher Lab-Blender 80 por 1 minuto. El análisis bacteriológico se realizó con muestras de $1 \mathrm{ml}$ del homogeneizado y realizando las diluciones apropiadas se sembró en placas de Tryptone Soya Agar suplementada con 2\% NaCl (TSA2, Oxoid) y Thiosulphate-Citrate-Bile Salt Sucrose Agar (TCBS, Oxoid) e incubadas a $20^{\circ} \mathrm{C}$ durante una semana.

Las bacterias probióticas utilizadas en este estudio fueron las cepas 11, 77 y C33, las cuales pertenecen a los géneros Pseudomonas, Arthrobacter y Vibrio, respectivamente. Estas bacterias se obtuvieron desde alimento y agua de un cultivo larval de A. purpuratus y 
se caracterizan por presentar actividad inhibitoria del crecimiento de diversos patógenos como Vibrio anguillarum (VAR), Vibrio esplendidus, Vibrio alginolyticus y Aeromonas hydrophila como ha sido demostrado previamente por Riquelme et al. (1997).

Como vector de incorporación de las bacterias benéficas se utilizó la microalga axénica Isochrysis galbana Parke (1938) (Culture Collection of Marine Phytoplankton, USA). En el cultivo microalgal para las dos primeras etapas se emplearon botellones de polietileno de $20 \mathrm{~L}$ con agua de mar filtrada a $0,2 \mu \mathrm{m}$ y autoclavada a $121^{\circ} \mathrm{C}$ por 15 minutos, los cuales fueron enriquecidos con la adición del medio de cultivo descrito para fitoplancton marino $\mathrm{F} / 2$ (Guillard \& Ryther 1962). Para lograr una producción constante del alimento asociado a las bacterias benéficas para las etapas "in vitro" y piloto, se inoculó dos botellones con la microalga en una concentración $10^{6}$ células $\mathrm{x} \mathrm{mL}^{-1}$. La incubación de los cultivos se realizó en ambiente controlado a $20 \pm 1{ }^{\circ} \mathrm{C}$, fotoperíodo constante de $24 \mathrm{~h}$ luz, intensidad de $50 \mu \mathrm{m} \mathrm{m}^{-2} \mathrm{~s}^{-1}$ y aireación continua con filtración $0,2 \mu \mathrm{m}$. Para evitar diferencias en los resultados sólo se utilizaron cultivos en fase estacionaria (Fox 1983), la cual fue determinada previamente mediante curvas de crecimiento de la microalga en idénticas condiciones a las de este estudio (Avendaño \& Riquelme 1999).

\section{Etapa I: Ensayos "in vitro".}

Para evaluar la ingestión de las bacterias benéficas en los ejemplares de $A$. purpuratus, se utilizó el procedimiento descrito por Baker \& Mann (1994) y Farias et al. (1997). 14 ejemplares adultos de $A$. purpuratus fueron cepillados y lavados repetidamente con agua de mar estéril, eliminando epífitos y organismos presentes en las valvas.

14 ejemplares se colocaron en un acuario con $20 \mathrm{~L}$ de agua de mar filtrada a $0,2 \mu \mathrm{m}$ y aireación continua para mantenerlos en ayuno durante 24 horas. Posteriormente, cada ejemplar fue distribuido en un vaso precipitado (Pyrex) con $1 \mathrm{~L}$ de agua de mar filtrada a $0,2 \mu \mathrm{m}$ y expuestos a la adición de cultivos bacterianos puros y mezclados utilizando los siguientes tratamientos:

a. Control (CT): Un ejemplar en agua de mar filtrada $(0,2 \mu \mathrm{m})$ sin la adición de alimento y bacterias.

b. Control microalga (CM): Un ejemplar en agua de mar filtrada $(0,2 \mu \mathrm{m})$ con la adición de I. galbana axénica a una concentración de $2 \times 10^{4}$ células $\times \mathrm{mL}^{-1}$.

c. Mezcla de bacterias (MIX): Un ejemplar en agua de mar filtrada $(0,2 \mu \mathrm{m})$ con la adición de las cepas benéficas 11,77 y C33 en una concentración por cepa de $5 \times 10^{3}$ células $\times \mathrm{mL}^{-1}$. d. Microalga y mezcla de bacterias (MBP): Un ejemplar en agua de mar filtrada $(0,2 \mu \mathrm{m})$ con la incorporación de $I$. galbana $\left(2 \times 10^{4}\right.$ células $\left.\mathrm{x} \mathrm{mL}^{-1}\right)$ y la adición de las tres cepas benéficas en mezcla en una concentración de $5 \times 10^{3}$ células $\times \mathrm{mL}^{-1}$ de cada una.

e. Bacteria 11 (11): Un ejemplar en agua de mar filtrada $(0,2 \mu \mathrm{m})$ con la adición de la cepa 11 a una concentración de $5 \times 10^{3}$ células $\mathrm{mL}^{-1}$.

f. Bacteria 77 (77): Un ejemplar en agua de mar filtrada $(0,2 \mu \mathrm{m})$ con la incorporación de la cepa 77 a una concentración de $5 \times 10^{3}$ células $\times \mathrm{mL}^{-1}$.

g. Bacteria C33 (C33): Un ejemplar en agua de mar filtrada $(0,2 \mu \mathrm{m})$ con la adición de la cepa $\mathrm{C} 33$ a una concentración de $5 \times 10^{3}$ células $\times \mathrm{mL}^{-1}$.

La ingestión de las cepas benéficas se determinó mediante el análisis bacteriológico del agua de cultivo al inicio de la experiencia y después de 60 minutos. Para ello, se tomaron muestras de $1 \mathrm{~mL}$ y realizando diluciones apropiadas se sembró en placas de TSA2 y TCBS. Posteriormente, las placas fueron incubadas a $20^{\circ} \mathrm{C}$ durante una semana.

\section{Etapa II: Ensayos en cultivo piloto.}

Una vez determinada la ingestión de las bacterias adicionadas, se procedió a realizar la etapa piloto en cuatro estanques de fibra de vidrio de $200 \mathrm{~L}$ con circulación continua de agua de mar filtrada a $10 \mu \mathrm{m}$ (Cuno cartridge) y aireación permanente. Los ejemplares se distribuyeron en cada estanque en densidad de 21 individuos $/ \mathrm{m}^{2}$. La experiencia se realizó alimentando durante 30 días los organismos con los siguientes regímenes alimenticios:

a. Dieta A (CT): Mezcla de I. galbana y Chaetoceros calcitrans, en una proporción 1:1 en concentración de $2 \times 10^{4}$ células $\times \mathrm{mL}^{-1}$.

b. Dieta B (MBP): Mezcla de I. galbana y $C$. calcitrans con la adición de las cepas 11,77 y C33 en concentración de $5 \times 10^{3}$ células $\times \mathrm{mL}^{-1}$.

El establecimiento de las bacterias benéficas en el tracto digestivo e infección gonadal de los ejemplares de A. purpuratus, se evaluó mediante análisis bacteriológico e histólogico de seis individuos al inicio de la experiencia y en los tiempos 15 y 30 días de cultivo. Para ello, los ejemplares fueron separados aleatoriamente, lavados repetidamente con SSM y disectados para extraerles el tracto digestivo y gónada. Posteriormente los tejidos fueron sometidos a los siguientes análisis:

a) Bacteriológico:

Se realizó de acuerdo a la metodología descrita 
previamente con los organismos silvestres. La determinación del porcentaje de bacterias benéficas establecidas en el tracto digestivo y la infección de éstas en la gónada para cada tiempo de estudio $(0,15$ y 30 días), se realizó de acuerdo a Riquelme et al. (2000). Para ello, se aislaron los diferentes morfotipos crecidos en las placas de TSA2 y mediante recuentos selectivos de Unidades Formadoras de Colonias (UFC), tinción Gram y test bioquímicos de identificación (Api20E, Bio Mérieux) se calculó el porcentaje de bacterias benéficas presentes en relación a las bacterias cultivables totales.

b) Histológico:

La obtención de cortes histológicos se realizó extrayendo de cada organismo una muestra del tracto digestivo de 0,5 a $1 \mathrm{~cm}$ de espesor, las cuales fueron tratadas mediante la técnica descrita por López et al. (1982) y modificada por Di Fiore (1986). La detección de las bacterias en los tejidos se realizó observando las placas con los cortes histológicos en un microscopio óptico Olympus BH-2 con magnificación $1000 \mathrm{X}$.

\section{Etapa III: Ensayos en cultivo masivo}

Los ensayos masivos se realizaron con 250 ejemplares adultos, los cuales fueron extraídos desde las líneas de cultivo de CMI y distribuidos en dos estanques de fibra de vidrio de $2000 \mathrm{~L}$ con agua de mar filtrada a $10 \mu \mathrm{m}$ y flujo constante. El sistema de alimentación en ambos estanques consistió en un bidón con $100 \mathrm{~L}$ de alimento unido a una tubería central, con el objeto de distribuir homogéneamente el alimento. La alimentación de los ostiones se realizó en forma continua $\left(5 \times 10^{-3} \mathrm{~L} \mathrm{x} \mathrm{s}^{-1}\right)$ con los siguientes tratamientos:

a. Dieta Control (CT): Mezcla de las cepas microalgales $I$. galbana y $C$. calcitrans a una concentración aproximada de $3 \times 10^{6}$ células $\mathrm{x} \mathrm{mL}^{-1}$ de cada especie.

b. Dieta MBP: Mezcla microalga-bacteria (I. galbana asociada a las bacterias 11,77 y C33) y $C$. calcitrans, ambas microalgas en una concentración aproximada de $3 \times 10^{6}$ células $\mathrm{x} \mathrm{mL}^{-1}$.

La producción de I. galbana se realizó de acuerdo al protocolo de la empresa, que consta de tres etapas de cultivo a) primario, b) intermedio y c) masivo. La etapa inicial se desarrolló en matraces (Pyrex) de $200 \mathrm{~mL}$ con la incorporación de las cepas benéficas 11, 77 y C33 todas en una concentración $5 \times 10^{3}$ células $\times \mathrm{mL}^{-1}$. Después de cuatro días de cultivo, los matraces fueron traspasados a botellones y al cuarto día dos botellones fueron transferidos a estanques de cultivo microalgales masivos denominados "kalwalls" de 200 L. Paralelamente, como control se mantuvo el cultivo de $I$. galbana sin la adición de bacterias benéficas.

Para determinar la permanencia y concentración de las cepas bacterianas al finalizar cada etapa de cultivo microalgal, se procedió a realizar el análisis bacteriológico de I. galbana, sembrando al finalizar cada etapa muestras microalgales sobre placas de TSA2 de acuerdo a la metodología descrita en la etapa "in vitro".

La presencia de las bacterias benéficas en el tracto digestivo y la infección de estas en la gónada de los ejemplares de A. purpuratus se determinó mediante análisis bacteriológicos de los individuos al inicio de la experiencia y en los tiempos de cultivo 15 y 30 días. Los muestreos se realizaron tomando aleatoriamente 10 organismos desde el estanque de experimentación. El análisis bacteriológico de los tejidos se realizó utilizando la metodología descrita en los ensayos pilotos. Paralelamente, se efectúo el análisis bacteriano del alimento entregado a los ejemplares de $A$. purpuratus, el agua de entrada y agua circulante dentro del estanque de confinamiento. Estas muestras fueron sembradas en placas de TSA2 e incubadas a $20^{\circ} \mathrm{C}$ por una semana.

Para comparar la ingestión y carga bacteriana entre los tratamientos y el control, los resultados obtenidos en las etapas "in vitro", piloto y masivo fueron sometidos a un ANOVA y Test de Comparaciones Múltiples LSD (Sokal \& Rohlf 1980).

\section{Resultados}

\section{Análisis bacteriológico de especimenes del medio natural}

El análisis cuantitativo de bacterias heterótrofas totales en los ejemplares de $A$. purpuratus previo al período de acondicionamiento, mostró valores aproximados en el digestivo y gónada de $4 \times 10^{4} \mathrm{UFC} \mathrm{g} \mathrm{g}^{-1}$ (Fig. 1). El recuento de vibrionaceas totales alcanzó una concentración 5 veces mayor en el tejido reproductivo en comparación a los valores obtenidos en el tracto digestivo $\left(3 \times 10^{2} \mathrm{UFC} \mathrm{g}^{-1}\right)$.

\section{Etapa I: Ensayos "in vitro"}

Los resultados de ingestión en ejemplares adultos expuestos a las bacterias benéficas después de 60 minutos de incubación, revelan la disminución de la carga bacteriana en el agua de todos los tratamientos (Fig. 2). Sin embargo, el análisis estadístico detectó diferencias significativas sólo en los ejemplares expuestos con las bacterias 11 y C33, las cuales fueron ingeridas en un $92 \%(\mathrm{P}<0,05)$. Cabe destacar que esta ingestión disminuye notablemente cuando las bacterias son adicionadas en mezcla $(44,06 \%)$ y asociadas a $I$. galbana $(26,76 \%)$. 


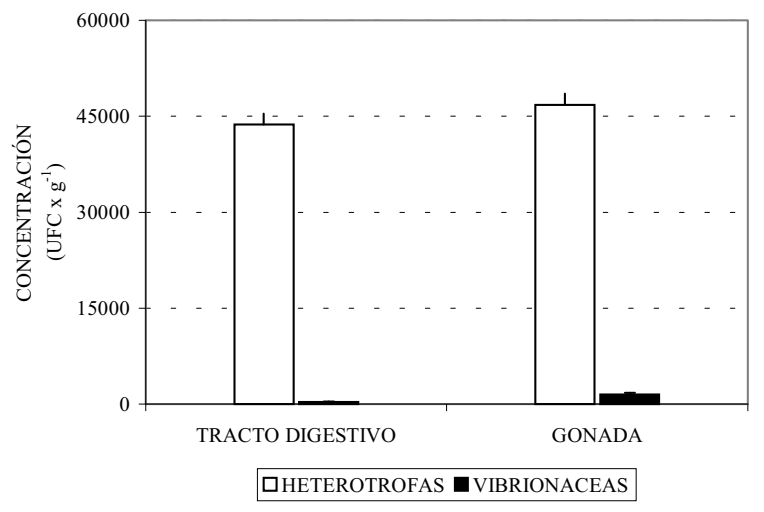

Figura 1

Recuento de bacterias heterotróficas y vibrionaceas totales en el tejido de los ejemplares adultos de $A$. purpuratus obtenidos desde el medio natural. UFC $=$ Unidad Formadora de Colonias. Las líneas verticales corresponden a la D.S.

Counts of total heterotrophic bacteria and vibrionaceae in tissues of adult A. purpuratus obtained from natural environment. $\mathrm{CFU}=$ colony forming unit. Vertical lines $=$ one standard deviation

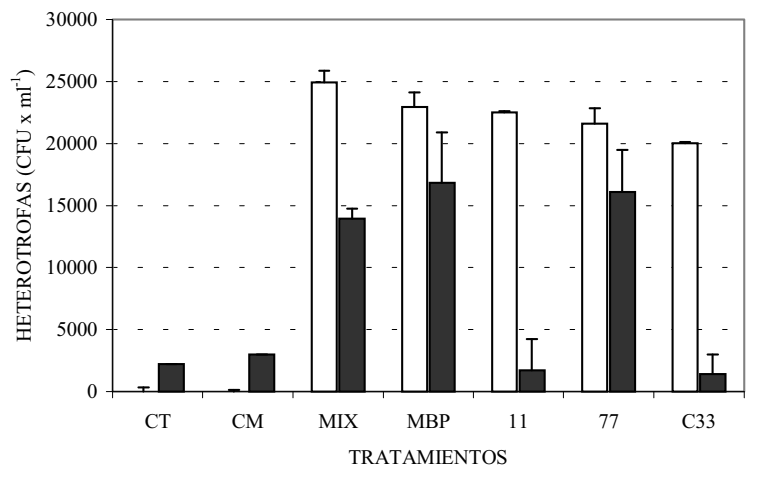

$\square 0 \mathrm{~h} \square 1 \mathrm{~h}$

Figura 2

Ingestión bacteriana de adultos de $A$. purpuratus expuestos con las cepas bacterianas 11,77 y $\mathbf{C 3 3}$ y la microalga $I$. galbana, al inicio y después de 60 minutos de incubación a una concentración $5 \times 10^{3}$ células $\times \mathrm{ml}^{-1}$. CT= control; $\mathrm{CM}=$ control microalga; $\mathrm{MIX}=$ mezcla de bacterias; $\mathrm{MBP}=$ microalga $\mathrm{y}$ mezcla de bacterias $(11,77$ y $\mathrm{C33})$. UFC $=$ Unidades Formadoras de Colonias.

Bacterial ingestion by adult $A$. purpuratus exposed to bacterial strains 11, 77 and $\mathrm{C} 33$ and the microalga I. galbana at initiation and after $60 \mathrm{~min}$ incubation in a concentration of $5 \mathrm{x}$ $10^{3}$ cells $\mathrm{ml}^{-1}$. $\mathrm{CT}=$ control; $\mathrm{CM}=$ microalgal control; $\mathrm{MIX}=$ bacterial mixture; $\mathrm{MBP}=$ microalgae plus bacterial mix (11, 77, and $\mathrm{C} 33 \cdot)$. $\mathrm{CFU}=$ colony forming unit.
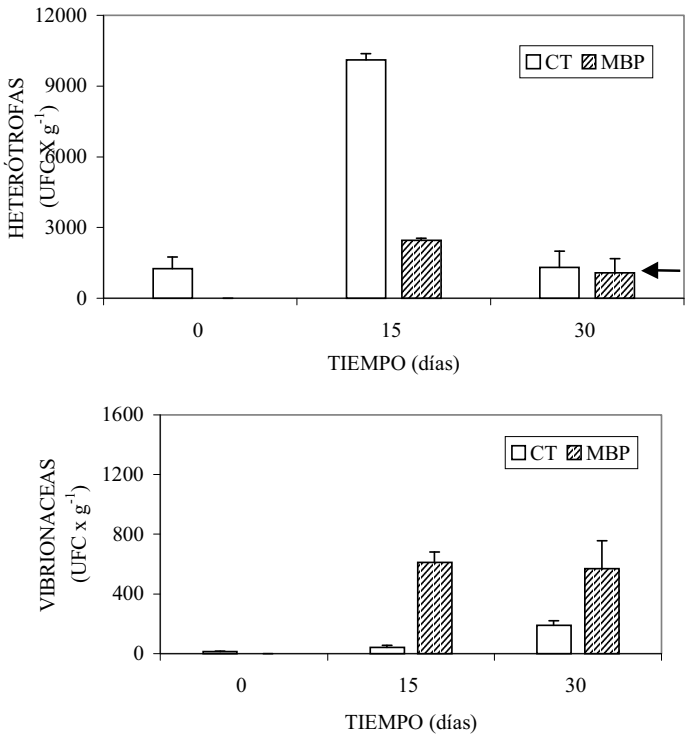

Figura 3

Recuento de bacterias heterótrofas y vibrionáceas totales en el tracto digestivo de $A$. purpuratus durante los 30 días de duración de la etapa de ensayos pilotos. La flecha indica la presencia de la cepa $11(41,8 \%)$. CT = control y MBP = microalga- bacterias.

Counts of heterotrophic bacteria and vibrionaceae in the digestive tract of $A$. purpuratus over the 30 day duration of the pilot assays. Arrow indicates presence of strain 11 (41.8\%). $\mathrm{CT}=$ control, $\mathrm{MBP}=$ microalgae-bacteria.

\section{Etapa II: Ensayos en cultivo piloto}

Los análisis bacteriológicos del tracto digestivo de los ejemplares alimentados con la dieta MPB no revelaron diferencias en la carga bacteriana en los distintos muestreos, fluctuando entre $1063 \pm 230$ a $2454 \pm 131$ UFC $\mathrm{x} \mathrm{g}^{-1}$ (Fig. 3). Sin embargo, en el caso de los controles el recuento de heterótrofas en el tracto digestivo no presentó un patrón definido, alcanzando en el día 15 de cultivo una concentración de $10122 \pm 250$ UFC $\mathrm{x} \mathrm{g}^{-1}$, la cual disminuyó en $87,12 \%$ al término de la experiencia. En el análisis de vibrionaceas, se observó un incremento de este grupo bacteriano en los organismos sometidos a la exposición de bacterias

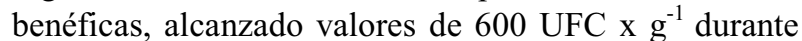
el período de estudio. Es importante señalar que en los ejemplares alimentados con la dieta MBP, sólo se detectó el establecimiento en el tracto digestivo de una de las bacterias adicionadas (cepa 11), alcanzando una colonización de $41,8 \%$ de la carga total.

Los análisis de heterótrofas totales en la gónada de los ejemplares sometidos a la dieta MBP, registran una carga bacteriana que fluctuó durante la experiencia entre 1336 y 2647 UFC x g ${ }^{-1}$ (Fig. 4), no detectándose la 
infección de las bacterias inoculadas en ninguno de los ejemplares muestreados. Con respecto a los controles se registró una situación similar a la presentada en los tractos digestivos. En relación con las concentraciones de vibrionaceas en el tejido gonadal durante el transcurso de la experiencia, estas fluctuaron entre 600 a 1200 UFC $\mathrm{x} \mathrm{g}^{-1}$. El análisis estadístico de la carga bacteriana de heterótrofas y vibrionaceas totales en el tracto digestivo y gónada expuestas a las dietas con y sin suplemento bacteriano, no mostraron diferencias

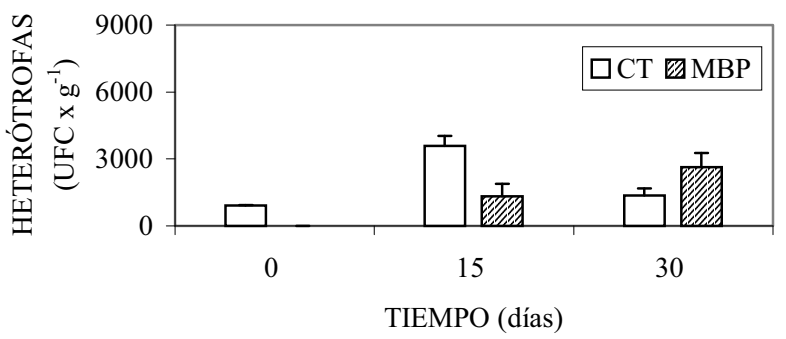

significativas $(\mathrm{P}>0,05)$.

El análisis de los cortes histológicos revela en los organismos expuestos al tratamiento de dieta MBP un incremento de las bacterias adheridas en las microvellosidades del epitelio del tracto digestivo de $A$. purpuratus (Fig. 5 a). Esta situación no fue observada en los tractos digestivos de los ostiones sin la adición de bacterias benéficas (Fig. 5 b).

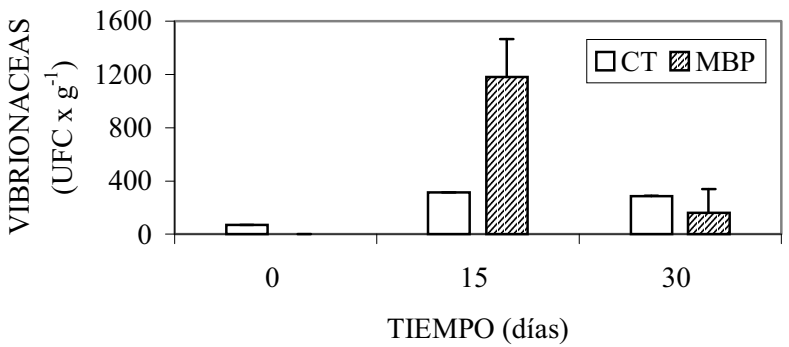

\section{Figura 4}

Recuento de bacterias heterótrofas y vibrionáceas totales en la gónada de A. purpuratus durante los 30 días de duración de la etapa de ensayos pilotos. $\mathrm{CT}=$ control y $\mathrm{MBP}=$ microalga-bacteria.

Total counts of heterotrophic bacteria and vibrionac eae in the gonads of $A$. purpuratus over the 30 day duration of the pilot assays. $\mathrm{CT}=$ control,, $\mathrm{MBP}=$ microalgae-bacteria.
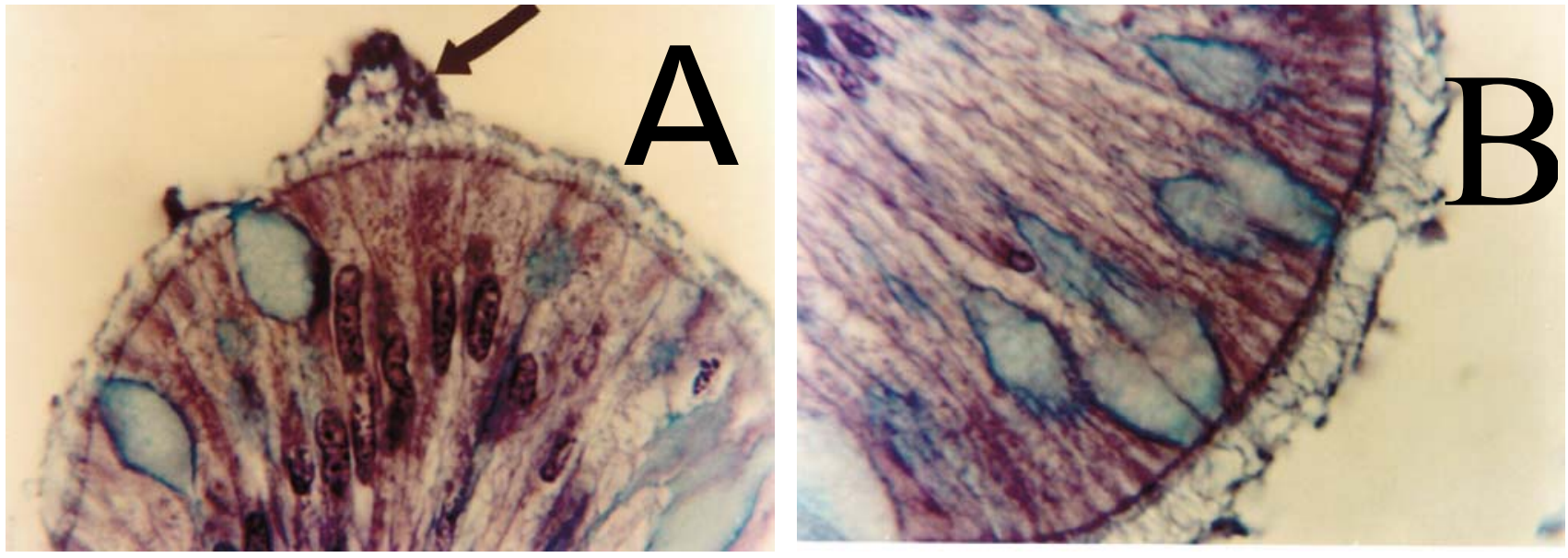

Figura 5

Microfotografía en microscopía de luz de una sección fina de microvellosidades del tracto digestivo de A. purpuratus. A) Tratamientos con adición de bacterias benéficas, la flecha indica bacterias adheridas al epitelio del tracto digestivo y B) Control, no se observan agregados bacterianos adheridos al epitelio.

Light microscopy photomicrograph of a fine section of microvilli in the digestive tract of $A$. purpuratus. A) Treatment with beneficial bacteria, with arrow showing these bacteria adhered to digestive tract epithelium, B) Control, where bacterial aggregates were not observed adhered to epithelium. 


\section{Etapa III: ensayos en cultivo masivo.}

Los resultados de permanencia y concentración de las cepas bacterianas 11,77 y C33 en las diferentes etapas de los cultivos microalgales se muestran en la Tabla 1. Esta revela el incremento significativo de la cepa 11 durante el escalamiento del cultivo, alcanzando al cuarto día un $97,7 \pm 1,88 \%$ de la carga bacteriana presente en la dieta MBP. Esto no ocurre con las cepas 77 y C33, las cuales disminuyeron a porcentajes promedios de 1,58 y $0,71 \%$, respectivamente.

Los resultados de la carga bacteriana en el tracto digestivo de ejemplares de A. purpuratus del estanque revelan el asentamiento de la cepa 11 en todos los organismos alimentados con la MBP, fluctuando entre 34,12 a $75,64 \%$, desde el día 15 de cultivo hasta el final de la experiencia. De igual modo, se detectó durante los treinta días de cultivo la presencia de concentraciones homogéneas de la cepa 11 en la gónada de los organismos estudiados, la cual alcanza un porcentaje promedio de 71,61 \pm 4 . Además, se registro la presencia de la cepa C33 en concentraciones de $10^{2}$ UFC x g ${ }^{-1}$ en todos los ejemplares muestreados a los 15 días de cultivo.

Los resultados obtenidos en los análisis bacterianos realizados en el alimento registran una alta carga bacteriana, alcanzando $2,7 \times 10^{5} \pm 1,5 \times 10^{3} \mathrm{UFC} \mathrm{x} \mathrm{mL}^{-1}$, constituida por un $72,34 \pm 5,64 \%$ de la cepa 11 . En relación a la carga total de heterótrofas en el agua de entrada del cultivo, esta fluctuó entre $200 \pm 55$ UFC x $\mathrm{mL}^{-1}$ durante el estudio. Además, se observa un notorio incremento de la carga bacteriana del agua de entrada del estanque, alcanzando una concentración de $5 \times 10^{3}$ \pm 75 UFC $\times \mathrm{mL}^{-1}$, disminuyendo un $89,44 \%$ a la salida. El análisis estadístico de la carga bacteriana de heterótrofas totales en el tracto digestivo y gónada de los ejemplares de A. purpuratus expuestos a la dieta MBP mostraron diferencias significativas $(\mathrm{P}<0,05)$ en comparación a la dieta control, aportando en gran porcentaje a dicha diferencia la cepa 11 .

Además, es importante considerar que la adición constante de cepas 11, 77 y C33 empleando el vector microalga no causó efectos en la sobrevivencia en ostiones expuestos a estas durante el transcurso de las tres etapas.

\section{Discusión}

Las concentraciones de bacterias en el tracto digestivo de los ejemplares de A. purpuratus obtenidos del medio natural en este estudio, difiere de las concentraciones reportadas por Jorquera et al. (1999), las cuales muestran valores cercanos a los $10^{5}$ UFC x g ${ }^{-1}$. Sin embargo, la carga bacteriana en la gónada de adultos de A. purpuratus resultó ser similar a los valores registrados por Riquelme et al. (1995b), siendo considerada por estos autores como una concentración alta para este tejido. Es interesante destacar que la alta carga de heterótrofas detectada en este trabajo contiene

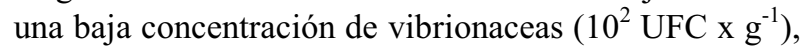
resultados que difieren en este aspecto con los registrados por Riquelme et al. (1995a) $\left(2,4 \times 10^{3}\right.$ UFC $\mathrm{x} \mathrm{g}^{-1}$ ), que fueron obtenidos durante el desarrollo de una epizootia provocada por Vibrio anguillarum (VAR) siendo esta la principal causa del incremento de Vibrio spp. en los tejidos de los ejemplares analizados. Por otro lado, la presencia constante de bacterias en los tejidos de moluscos bivalvos es considerada un fenómeno natural, ya que debido a su capacidad de filtrar diferentes partículas entre ellas las bacterias, concentraría en sus órganos una mayor carga de estos microorganismos en comparación con otros invertebrados marinos (Prieur et al. 1990, Araya et al. 1999).

Los resultados sobre la ingestión de las cepas evaluadas, muestran una disminución de la concentración de bacterias en el agua de cultivo de todos los ensayos con excepción de los controles. Probablemente, este resultado se 
debe a que los bivalvos y en particular los pectínidos, como condición fisiológica, filtran constantemente el agua circulante, incrementándose la tasa de ingestión de partículas de acuerdo al tamaño corporal de los organismos (Winter et al. 1984, Calahan et al. 1989). Además, el período de duración de la experiencia $(1 \mathrm{~h})$ permitió controlar posibles ritmos de filtración que generalmente muestran los organismos filtradores (Araya et al. 1993), detectando la ingestión de las bacterias 11 y C33, cuando estas cepas fueron adicionadas en forma directa en el agua de cultivo de $A$. purpuratus, lo cual indicaría un grado de selectividad de los ejemplares adultos por estas cepas, ya que los resultados de los restantes tratamientos son notablemente menores. Sin embargo, Beninger \& Le Pennec (1991), señalan que pectínidos adultos seleccionan las partículas presentes en el medio acuático de acuerdo a su tamaño, no discriminando aparentemente entre los diferentes tipos de partículas en forma cualitativa. Estudios de ingestión adicionando en forma directa las cepas 11, 77 y C33 al agua de cultivo de larvas de $A$. purpuratus, revelan coincidentemente a nuestros resultados la ingestión selectiva de la bacteria 11 (Riquelme et al. 2000). Ensayos preliminares de ingestión en larvas de A. purpuratus adicionando las mismas bacterias, en forma directa y asociadas a $I$. galbana, demostraron una eficiente ingestión de las cepas 11 y C33, cuando estas son inoculadas directamente al agua y asociadas a la microalga (Avendaño \& Riquelme 1999). Es importante destacar la coincidente ingestión selectiva de las cepas 11 y C33 por larvas y adultos de $A$. purpuratus, las cuales son ingeridas en mayor o menor porcentaje dependiendo de la forma de adición. Esta selectividad podría ser de tipo nutritivo, ya que bivalvos pueden utilizar directamente las bacterias como fuente de alimento (Douillet 1991, Alber \& Valiela 1996). La presencia de bacterias en el agua de incubación en los controles, probablemente se debe a la incorporación de los ejemplares de $A$. purpuratus en el agua de cultivo. Estos organismos poseen una bacterioflora asociada o residente la que podría ser transferida al agua estéril (Moriarty 1990).

En cuanto a la detección, solamente de la bacteria 11 $(41,8 \%)$ se estableció en el tracto digestivo de $A$. purpuratus (30 días, etapa piloto). Estudios realizados por Gatesoupe (1999), señalan que la colonización de la flora bacteriana gastrointestinal en organismos marinos tiene una particular dependencia del medio externo, especialmente en moluscos filtradores y peces, situación que está relacionada con el flujo de agua que pasa por el tracto digestivo de estos organismos. Otros factores que podrían haber incidido en el bajo y tardío establecimiento de las bacterias benéficas fue la circulación continua del agua de cultivo al momento de alimentar y la baja concentración bacteriana de la dieta $\left(5 \times 10^{3}\right.$ células $\mathrm{x}$
$\left.\mathrm{mL}^{-1}\right)$. Gibson et al. (1998), mostraron que la colonización en larvas de "ostra del pacífico" (Crassostrea gigas T) con la bacteria probiótica Aeromonas media ocurre con concentraciones superiores a $1 \times 10^{4} \mathrm{UFC} \times \mathrm{mL}^{-1}$. Ringo \& Vadstein (1998), describen que el establecimiento y temprana colonización de Vibrio pelagius y Aeromonas caviae en larvas de "turbot" (Scophthalmus maximus L) es factible siempre que la densidad bacteriana sea alta. GournierChateau et al. (1994), señalan que una bacteria transiente podría ser una eficiente colonizadora siempre que las células sean introducidas en altas dosis, de forma continua o semicontinua

Las concentraciones menores de bacterias heterótrofas registradas en los tractos digestivos de los ejemplares alimentados con I. galbana asociada a las cepas 11, 77 y C33, en comparación a los controles, pueden ser atribuidas a la disminución de la carga bacteriana en el agua influenciada por estas bacterias productoras de inhibitorios. Riquelme et al. (2001) y Araya et al. (1999), señalan que la adición de un antagonista bacteriano podría implicar el desplazamiento de bacterias por la producción de componentes inhibitorios, relaciones competitivas del espacio y una mejor utilización del sustrato. La evaluación a nivel histológico mostró un gran número de bacterias, las cuales se encontraban formando una biopelícula en las microvellosidades del epitelio del tracto digestivo en los ejemplares analizados, coincidentemente con la alta densidad de colonización de la cepa 11. Experiencias realizadas "in vitro" con el objeto de incorporar la cepa 11 en larvas de $A$. purpuratus mediante la inmersión de éstas en agua de mar con la adición de los potenciales probióticos, permitieron observar mediante microscopía electrónica la colonización de esta cepa en forma predominante en el tracto digestivo de larvas (Araya et al. 1999). Además, Johansen et al. (1997), demostraron que ciertas bacterias son capaces de adherirse y colonizar superficies en distintos ambientes, debido a la capacidad de sintetizar exopolisacáridos. Estudios realizados con Pseudomonas aeruginosa reportaron la capacidad de algunas bacterias de formar complejas estructuras debido a la secreción de alginato (exopolímero), el cual actuaría como sustrato de adhesión, facilitando la formación de microcolonias bacterianas (Elasri \& Miller 1999).

En relación a la etapa de ensayos masivos, es importante destacar el aumento de la concentración final de la cepa 11 (97,7\%), transcurridas las diferentes etapas de los cultivos microalgales. Este incremento podría relacionarse con la rápida tasa generacional de esta bacteria cuando esta asociada a I. galbana, provocando el desplazamiento de las cepas 77 y C33 (Avendaño \& Riquelme 1999). Lo anterior se explica 
por el hecho que las microalgas liberan exudados algales, que actúan como promotores o inhibidores del crecimiento bacteriano (Abarzúa et al. 1995, Riquelme et al. 2000). Estudios realizados por Avendaño \& Riquelme (1999), en microalgas como alimento para larvas de ostión demostraron que cultivos monoaxénicos de I. galbana asociados a las cepas 11 y 77 alcanzan concentraciones de $10^{6}$ UFC $\times \mathrm{mL}^{-1}$, en comparación a la bacteria C33 $\left(10^{4}\right.$ UFC $\left.\mathrm{x} \mathrm{mL} \mathrm{mL}^{-1}\right)$. Probablemente, esta mayor proliferación se deba a que ambas cepas fueron originalmente aisladas desde cultivos microalgales (Riquelme et al. 1997). Por otro lado, antecedentes obtenidos por Lodeiros et al. (1991), señalan la existencia de cierta especificidad entre los monocultivos microalgales y sus bacterias asociadas.

El efecto de la adición de la mezcla de bacteria y microalga (MBP) en sistemas masivos, difiere de lo ocurrido en los ensayos pilotos, demostrando el establecimiento en forma dominante de la cepa 11 en el tracto digestivo y gónada en todos los ejemplares a partir de los 15 días de cultivo. Probablemente, la rápida colonización de los tejidos en la etapa masiva se debe a la optimización del modelo experimental, ingresando en forma continua y en una concentración mil veces mayor de bacterias benéficas a los estanques de experimentación, en comparación a la etapa piloto. La importancia de la concentración adicionada de probióticos en sistemas experimentales fue recientemente informada por Gram et al. (1999), quienes en estudios realizados en peces infectados con Vibrio anguillarum dan cuenta del control efectivo de este agente patógeno por medio de la utilización de Pseudomonas fluorescens en concentraciones que variaron desde $10^{7}$ a $10^{9}$ UFC $\mathrm{x} \quad \mathrm{mL}^{-1}$. Estas concentraciones facilitarían según los autores la posible colonización y multiplicación del antagonista en el huésped.

Con respecto a la infección en gónada de las bacterias 11 y C33, podría originarse por el paso de la cepa benéfica desde intestino hacia las gónadas, ya que este órgano cruza en dos secciones la gónada de $A$. purpuratus (Riquelme et al. 1994) . Por lo tanto se puede sugerir que los gametos podrían ser portadores de las bacterias benéficas desde adultos a larvas. Previamente ha sido demostrada la existencia de la transmisión vertical de bacterias en $A$. purpuratus (Riquelme et al. 1994). Esta situación podría ser aprovechada benéficamente utilizando reproductores acondicionados con bacterias probióticas, lo que puede dar como resultado la incorporación de estas bacterias en las larvas.

El establecimiento de una microflora bacteriana benéfica modificada ( 11 y C33), podría participar en el sistema de defensa previniendo la colonización de bacterias patógenas (Prieur et al. 1990, Austin et al. 1995, Bergh 1995). La colonización del agente probiótico en el tracto digestivo en forma dominante, favorecería la sanitización natural del organismo y mejoraría la resistencia inherente a la invasión microbiana (Lemos et al. 1985, Nogami \& Maeda 1992, Araya et al. 1999).

Los resultados indican que el alimento puede ser utilizado en forma exitosa como vector de bacterias benéficas, permitiendo el establecimiento de las cepas 11 y $\mathrm{C} 33$ en el tracto digestivo de reproductores. Además, la infección de la gónada facilitaría la manipulación microbiológica de reproductores y su descendencia.

\section{Agradecimientos}

Este estudio fue financiado por el proyecto FONDEF D97I2033. Los autores agradecen la revisión y comentarios del profesor Ismael Kong U. Se agradece al profesor Alberto Olivares por su valiosa colaboración en los análisis histológicos.

\section{Literatura Citada}

Abarzúa M, S Basualto \& H Urrutia. 1995. Relación entre la abundancia y la biomasa de fitoplancton y bacterioplancton heterotrófico en aguas superficiales del Golfo de Arauco, Chile. Investigaciones Marinas Valparaíso. 23: 67-74.

Alber M \& I Valiela. 1996. Utilization of microbial organic aggregates by bay scallops Argopecten irradians (Lamarck). Journal of Experimental Marine Biology and Ecology. 195: 71- 89.

Araya P, A Pozo, M Avendaño. \& R Escribano.1993. Dinámica de alimentación de individuos Argopecten purpuratus L. En condiciones de laboratorio. Revista de Biología Marina, Valparaíso 28 (2): 313-329.

Araya R, M Jorquera \& C Riquelme. 1999. Asociación de bacterias al ciclo de vida de Argopecten purpuratus. Revista Chilena de Historia Natural. 72: 261-271.

Austin B. 1988. Marine Microbiology. Cambridge University Press, London. 221.

Austin B, L Stuckey, P Roberston, I Effendi \& D Griffith. 1995. A probiotic strain of Vibrio alginolyticus effective in reducing disease caused by Aeromonas salmonicida, Vibrio anguillarum and Vibrio ordalli. Journal of Fish Diseases. 18:93 - 96.

Avendaño R \& C Riquelme. 1999. Establishment of mixedculture probiotics and microalgae as food for bivalve larvae. Aquaculture Research. 30: 893-900.

Baker S \& R Mann. 1994. Feeding ability during settlement and metamorphosis in the oyster Crassostrea virginica (Gmelin, 1791) and the effects of hypoxia on postsettlement ingestion rates. Journal of Experimental Marine Biology and Ecology. 181: 239-253. 
Beninger P. \& Le Pennec M. 1991. Functional anatomy of scallops. En: Scallop: Biology, ecology and aquaculture. S.E. Shumway (Ed.). Elsevier - Amsterdam. 133-209.

Bergh O. 1995. Bacteria associated with early life stages of halibut, Hippoglossus hipoglossus L., inhibit growth of patogenic Vibrio sp. Journal of Fish Diseases. 18: 93-96.

Boyd C. \& L Massaut. 1999. Risk associated with the use of chemicals in pond aquaculture . Aquacultural Engineering. $20: 113-132$.

Calahan JA, SE Siddall \& MW Luckenbach. 1989. Effect of flow velocity, food concentration and particle flux on the growth rates of juvenile bay scallop Argopecten irradians. Journal of Experimental Marine Biology and Ecology. 129: 45-60.

Di Fiore M. 1986. Diagnóstico Histológico. De Ateneo. Tomo I. 9 Edición. 143.

Disalvo L. 1991. Vibriosis y problemas del cultivo de ostión (Argopecten purpuratus). En: IV Congreso Latinoamericano de Ciencias del Mar. 30 septiembre -4 octubre. 172 pp.

Douillet P. 1991. Beneficals effects of bacteria on the culture of larvae of the pacific oyster Crassostrea gigas (Thunberg). Ph D. Oregon State University, 185.

Douillet P \& C Langdon. 1993. Effects of marine bacteria on the culture axenic Oyster Crassostrea gigas (Thunberg) larvae. Biology Bulletin. 184: 36 - 51.

Elasri M. \& R Miller. 1999. Study of the response of a biofilms bacterial community to UV radiation. Applied and Environmental Microbiology 65 (5): 2025 - 2031.

Elston RA. 1984. Prevention and management of infection diseases in intensive mollusc. Husbandry. Journal World Mariculture Society. 15: $284-300$.

Farías A, I Uriarte. \& P Varas. 1997. Estudios de los requerimientos nutricionales del ostión del norte Argopecten purpuratus (Lamarck, 1819) durante el acondicionamiento reproductivo. Revista de Biología Marina y Oceanografía. 32 (2): 127 - 136.

Fitt W, G Heslinga \& T Watson. 1992. Use of antibiotics in the mariculture of giant clams (F.Tridacnidae). Aquaculture. 104: 1-10.

Fox J. 1983. Intensive algal culture techniques. J Mcvey (Ed.): Handbook of mariculture. Volume 1. Crustaceans Aquaculture. CRC Press. Pp. 15-31.

Gatesoupe F. 1999. Review: The use of probiotics in aquaculture. Aquaculture. 180: 147-165.

Gibson L, J Woodworth \& A George. 1998. Probiotic activity of Aeromonas media on the Pacific oyster, Crassostrea gigas, when challenged with Vibrio tubiashii. Aquaculture. 169:111-120.

Gournier-Chateau N, J Larpent, I Castellanos \& J Larpent. 1994. Les probiotiques en alimentation animale et humaine. Technique et Documentation Lavoisier, Paris. $192 \mathrm{pp}$.
Gram 1, J Melchiorsen, B Spanggard, I Huber \& $T$ Nielsen. 1999 Inhibition of Vibrio anguillarum by Pseudomonas fluorescens $\mathrm{AH} 2$, a possible probiotic treatment of fish. Applied and Environmental Microbiology. 65: 969 - 973.

Guillard R. \& J Ryther. 1962. Studies of marine planktonic diatoms. Cyclotella nana, Hustedt and Detonula confervacea (Cleve). Canadian Journal of Microbiology. 8: 229-237.

Harzevili A, H Duffel, PH Dhert, J Swings \& P. Sorgeloos. 1998. Use of potential probiotic Lactococcus lactis AR21 stain for the enhancement of growth in the rotifer Brachionus plicatilis (Müller). Aquaculture Research. 29: $411-417$.

Johansen C, P Falholt \& L Gram. 1997. Enzymatic removal and disinfection of bacterial biofilms. Applied and Environmental Microbiology. 63 (9): 3724-3728.

Jorquera M, C Riquelme., L Loyola. \& L Muñoz. 1999. Production of bactericidal substance by a marine Vibrio isolated from cultures of the scallop Argopecten purpuratus. Aquaculture International. 7: 433-448.

Lemos M, A Toranzo \& J Barja. 1985. Antibiotic activity of epiphytic bacterial isolated from intertidial seaweeds. Microbial Ecology. 11:149 - 163.

Lodeiros C, Y Campos \& N. Marin. 1991. Producción de antibióticos por la flora bacteriana asociada a monocultivos microalgales de utilidad en acuacultura. Sociedad de Ciencias. Naturales. 136: 213 - 223.

López M, M Leyton \& A Graf. 1982. Técnicas de Histología y Citología. 230.

Lozano M. 2000. Compendio y directorio de la acuicultura y la Pesca de Chile. Aquanoticias Internacional. Technopress S.A. 355pp.

Moriarty D. 1990. Interactions of microorganisms and aquatic animals, particularly the nutritional role of the gut flora. Microbiology in Poecilotherms. 218 - 222.

Navarro R, L Sturla, O Cordero \& M Avendaño. 1991. Fsheries and aquaculture: Chile. In: Scallops: Biology, ecology and aquaculture. Elsevier Science Publisher, Amsterdam. 1001 - 1015.

Nogami K \& M Maeda. 1992. Bacteria as biocontrol agents for rearing larvae of the crab Portunus trituberculatus. Canadian Journal of Fish Aquatic Science. 49: 23373 2376.

Olsson J, A Westerdhal, P Coway \& S Kjelleberg. 1992. Intestinal colonization potential of turbot (Scophthalmus maximus) and dab (Limnda limnda) associated bacteria with inhibitory affects against Vibrio anguillarum. Applied and Environmental Microbiology. 58: 551 - 556.

O' Sullivan M., G Thornton, GC O' Sullivan \& J Collins. 1992. Probiotic bacteria: Myth or reality?. Trends Food Science and Technology. 3: 309 - 314. 
Prieur G, J Nicolas, A Plusquellec \& M Vigneulle. 1990. Interaction between bivalve mollusc and bacteria in the marine enviroments. Oceanography and Marine Biology Annual Review. 28: 227 - 352.

Reid G. 1999. The Scientific basis for probiotic strains of Lactobacillus. Applied and Environmental Microbiology. 65 (9): 3763 - 3766.

Rengpipat S, W Phianphak, S Piyatiratitivorakul \& M Piamsak. 1998. Effects of a probiotic bacterium on black tiger shrimp Penaeus monodon survival and growth. Aquaculture. 167: 301-313.

Ringo E. \& O Vadstein. 1998. Colonization of Vibrio pelagius and Aeromonas caviae in early developing turbot (Scophtalmus maximus) larvae. Journal of Applied Microbiology. 84: 227 - 233.

Riquelme C, P Chávez, Y Morales \& G Hayashida. 1994. Evidence for parental bacterial transfer to larvae in Argopecten purpuratus (Lamarck, 1819). Biological Research. 27: 129 -134.

Riquelme C, G Hayashida, A Toranzo, J Vilches, \& $\mathbf{P}$ Chavez. 1995a. Pathogenicity studies of a Vibrio anguillarum- related (VAR) strain causing an epizootic in Argopecten purpuratus larvae culture in Chile. Diseases Aquatic Organism. 22: $135-141$.

Riquelme C, G Hayashida, N Vergara, A Vasquez, Y Morales \& P Chavez. 1995b. Bacteriology of scallop Argopecten purpuratus (Lamarck, 1819) culture in Chile. Aquaculture. 138: 49-60.

Riquelme C, G Hayashida, R Araya, A Uchida, M Satomi \& Y Ishida. 1996a. Isolation of a native bacterial strain the scallop Argopecten purpuratus with inhibitory effects against pathogenic vibrios. Journal of Shellfish Research. 15: 369 - 374 .

Riquelme C, A Toranzo, J Barja, $\mathbf{N}$ Vergara \& $\mathbf{R}$ Araya. 1996b. Association of Aeromonas hydrophila and Vibrio alginolyticus with larval mortalities of Scallop (Argopecten purpuratus). Journal of Invertebrate Pathology. 67: $213-218$
Riquelme C, R Araya, N Vergara, A Rojas, M Guaita \& M Candia. 1997. Potential probiotic strain in the culture of the Chilean scallop Argopecten purpuratus (Lamarrck,1819). Aquaculture. 154: 17 - 26.

Riquelme C, R Araya \& R Escribano. 2000. Selective incorporation of bacteria by Argopecten purpuratus larvae: implications for the use of probiotics in culturing systems of the Chilean scallop. Aquaculture. 181: 25 - 36.

Riquelme C, M Jorquera, A Rojas, R Avendaño \& N Reyes. 2001. Addition of inhibitor-producing bacteria to mass cultures of Argopecten purpuratus larvae (Lamarck, 1819). Aquaculture. 192: 111-119.

Robert R, P Miner \& J Nicolas. 1996. Mortality control of scallops larvae in the hatchery. Aquaculture International. 4: $305-313$

Ruiz C, Román \& J Sanchez. 1995. Effect of three different marine bacteria strains on larval cultures of Pecten maximus. En: Book of abstracts, $10^{\text {th }}$ International Pectinid Workshop:113-114.

Skjermo J, \& O Vadstein. 1999. Techniques for microbial control in the intensive rearing of marine larvae. Aquaculture. 177: 333 - 343.

Sokal R. \& J Rohlf. 1980. Introducción a la bioestadística. Ed. Reverte S.A., Barcelona 362

Westerdahl A, J Olsson, S Kjelleberg \& P Conway. 1991. Isolation and characterization of turbot (Scophthalmus maximus) associated bacteria with inhibitory effects against Vibrio anguillarum. Applied and Environmental Microbiology. 57 (8): 2223 - 2228.

Winter J, M Acevedo \& Navarro. 1984. Quempillen estuary and experimental oyster cultivation station in southern Chile. Energy balance in Ostrea chilensis. Marine Ecology Progress Series 20: 151-164. 